\title{
Has the Approach of Healthcare Workers to Influenza Vaccine Changed due to the Pandemic? What are their Perspectives on COVID-19 Vaccine?
}

\section{Pandemi Nedeniyle Sağlık Çalışanlarının İnfluenza Aşısına Yaklaşımı Değişti mi? Covid-19 Aşısına Bakış Açıları Nelerdir?}

\author{
(Desibe Korkmaz', Gülnur Kul² $^{2}$ \\ 'Dışkapı Yıldııım Beyazıt Resarch Hospital, Department of Infectious and Clinical Microbiology Diseases, Ankara, Turkey \\ ${ }^{2}$ Kırıkhan State Hospital, Department of Infectious and Clinical Microbiology Diseases, Hatay, Turkey
}

\begin{abstract}
Objectives: Increasing influenza vaccine intake in healthcare workers during the pandemic period will benefit the management of respiratory tract infections. This study aimed to investigate the effects of COVID-19 pandemic on influenza vaccination and COVID-19 vaccine.

Material and Method: Healthcare workers were questioned over a survey about their status of having received the previous influenza vaccine and the influenza vaccine and COVID-19 vaccine this year. Their relationship with occupation, working in risky conditions and demographic characteristics of the individuals was investigated.

Results: 768 healthcare workers participated in our study. While the rate of those who received the influenza vaccine in 2019 was $19.1 \%(n=147)$ this rate was $27.5 \%(n=211)$ in $2020(p<0.001)$. While 101 of the 221 people who were vaccinated in 2020 were vaccinated in 2019,110 people agreed to be vaccinated in 2020 even though they were not vaccinated in 2019. Those who received the influenza vaccine in 2019 accepted to receive the vaccine in 2020 as well $(p<0.001)$ and it was observed that those who did not receive the vaccine in 2019 did not receive it in 2020, either $(p<0.001)$. The rate of physicians who accepted both vaccines was higher than the rate of the other groups. When those who accepted to receive the COVID-19 vaccine were analyzed it was observed that the rate of those who accepted to receive the influenza vaccine in 2019 and 2020 was significantly higher than the rate of those who did not $(p<0.001)$.

Conclusion: It has been understood with the COVID-19 pandemic, how important the vaccine is, and this awareness has also increased the vaccination rates of influenza in healthcare workers. In this period, we should encourage health workers for higher vaccination rates. One of the most important factors for vaccination is that get individuals to accept vaccination once.
\end{abstract}

Keywords: Influenza vaccine, COVID-19 pandemic, healthcare workers, COVID-19 vaccine
Öz

Amaç: Pandemi döneminde sağlık çalışanlarında influenza aşısı alımının arttıııması solunum yolu enfeksiyonlarının yönetimine fayda sağlayacaktır. Bu çalışma, COVID-19 pandemisinin influenza aşısı ve COVID-19 aşıı üzerindeki etkilerini araştırmayı amaçlamıştır.

Gereç ve Yöntem: Sağlık çalışanlarına, önceki yılki influenza aşısı ve bu yı influenza aşısı ve COVID-19 aşısı yaptırma durumları hakkında bir anket hazırlandı. Bireylerin demografik özellikleri, meslek ve riskli birimlerde çalışma durumları ile ilişkileri araştırıldı.

Bulgular: Çalışmamıza 768 sağ lık çalışanı katıldı. 2019 yıında influenza aşısı olanların oranı \%19,1 ( $n=147)$ iken 2020 yılında bu oran \%27,5 $(n=211)$ idi $(p<0,001) .2020$ 'de aşılanan 221 kişiden 101'i 2019'da aşılanırken, 110 kişi 2019'da aşı olmamasına rağmen 2020'de aşı olmayı kabul etti. 2019'da influenza aşısı olanların tamamı 2020'de de aşı olmayı kabul etti. ( $p<0,001) 2019$ yılında aşı yaptırmayanların 2020 yılında da yaptırmadığı görüldü $(p<0,001)$. Her iki aşıyı da kabul eden hekim oranı diğer gruplara göre daha yüksekti. COVID-19 aşısını yaptırmayı kabul edenler incelendiğinde 2019 ve 2020 yıllarında influenza aşısı olmayı kabul edenlerin oranının yaptırmayanlara göre anlamlı derecede yüksek olduğu görüldü $(p<0,001)$.

Sonuç: COVID-19 pandemisi ile aşının ne kadar önemli olduğu anlaşılmış ve bu farkındalık sağlık çalışanlarında influenza aşılama oranlarını da artırmıştır. Bu dönemde sağlık çalışanlarını daha yüksek aşı oranları için teşvik etmeliyiz. Aşılamanın en önemli faktörlerinden biri de aşıyı bir kez kabul ettirmektir.

Anahtar Kelimeler: İnfluenza aşısı, COVID-19 pandemisi, sağlık çalışanları, COVID-19 aşıSı

Corresponding (illetişim): Nesibe Korkmaz, Department of Infectious and Clinical Microbiology Diseases, MD, Dışkapı Yıldırım Beyazıt Resarch Hospital, Ankara, Turkey

E-mail (E-posta): nesibeaydogan@hotmail.com

Received (Geliș Tarihi): 08.07.2021Ａccepted (Kabul Tarihi): 07.09.2021 


\section{INTRODUCTION}

Influenza is an acute viral infection with high infectivity and mostly seen from the late fall to early spring. ${ }^{[1]}$ Although the influenza vaccine is recommended to the healthcare workers by the Centers for Disease Control and Prevention (CDC) every year the rates of vaccination are observed to be low. ${ }^{[2]}$ Healthcare workers are at high risk in terms of influenza and they can be a source of infection especially for immunocompromised patients. ${ }^{[3]}$

Coronavirus disease 2019 (COVID-19) was defined as a severe viral respiratory tract agent in the late 2019. ${ }^{[4]}$ COVID-19 disease was declared a global pandemic by the World Health Organization (WHO) in March, 2020. ${ }^{[5]}$ COVID-19 and influenza are viral infection agents that are transmitted through similar routes and that can show similar clinical symptoms such as fever, coughing and shortness of breath. Studies have revealed that coexistence of these two infections can cause severe clinical course and complications and fatal results. ${ }^{[6,7]}$

Both the healthcare workers and patients are protected with the influenza vaccine received by healthcare workers. Influenza-like diseases seen in patients and the length of stays in the intensive care unit and hospital decrease as well. ${ }^{[2]}$ It is not possible to decrease influenza due to low vaccination rates each year; however, the deficiency in vaccination will be more apparent this year due to the pandemic. ${ }^{[2]}$ Influenza and COVID-19 are together in circulation especially in winter months and have similar symptoms, which will cause difficulties in diagnosing. ${ }^{[1]}$ High vaccination rates not only decrease the influenza-associated mortality but also are of great importance in decreasing the load that can occur in the healthcare system due to COVID-19. When the safety of healthcare workers and patient health are considered reaching higher vaccination rates must be the national priority in the coexistence of COVID-19 and influenza. ${ }^{[2]}$

This study aimed to investigate the changes in attitudes and behaviors of the healthcare workers toward influenza vaccine due to pandemic and their attitude toward COVID-19 vaccine.

\section{MATERIAL AND METHOD}

Our study is a descriptive survey study and was performed on the healthcare workers between the $22^{\text {nd }}$ and $28^{\text {th }}$ of February 2021. After obtaining informed consent from participants, the questionnaire including 12 questions was sent to the healthcare workers over a survey. The participants were asked to anonymously complete the questionnaire. In the questionnaire, the healthcare workers were questioned about their demographic characteristics (age, occupation, gender, educational status, and chronic diseases), whether they worked for a unit with COVID-19 risk, whether they received the influenza vaccine last year or not, whether they received the influenza vaccine this year or not (yes or no), and whether they received the COVID-19 vaccine or not.
The healthcare workers who would like to receive the influenza vaccine received it until the end of December 2020 in our country. After COVID-19 vaccine was emergently approved by the Turkish Pharmaceuticals and Medical Devices Agency the first dose of vaccination was initiated for the healthcare workers in January 2021. When we started our study influenza vaccination of the healthcare workers was completed and the first dose of COVID-19 vaccine was administered. The study was prospectively performed and approved by the ethics committee of Mustafa Kemal University, Tayfur Ata Sokmen Faculty of Medicine (No:03 from february 18,2021$)$. All procedures were carried out in accordance with the ethical rules and the principles of the Declaration of Helsinki.

Categorical data in the study were expressed as numbers and percentiles. While Chi-Square Test was used in the comparisons between independent groups of the categorical variables Mc Nemar's Test was used in comparisons between the dependent groups. The analyses were performed with IBM SPPSS Package Software Program Version 24.0 (IBM Corporation, Armonk, NY, USA). Statistical significance level was $p<0.05$.

\section{RESULTS}

A total of 768 healthcare workers including 516 women (67\%), 252 men (33\%), 472 physicians (61\%), and 214 nurses (27\%) participated in the study. Median age of the participants in the study was 36.5 years.

When the status of having received the COVID-19 vaccine in 2020 was compared with the other factors stated in the table it was found that there was a statistically significant relationship in terms of occupation (While $23.4 \%$ of those who receive COVID-19 vaccine were nurses, $66.1 \%$ of those who received the COVID-19 vaccine were physicians.), rates of having received the influenza vaccine in 2019 (While $8.1 \%$ of those who did not receive the COVID-19 vaccine received the influenza vaccine in 2019 21.8\% of those who received the COVID-19 vaccine received the influenza vaccine in 2019.) and rates of having received the influenza vaccine in 2020 (While $7.4 \%$ of those who did not receive the COVID-19 vaccine received the influenza vaccine in $202032.3 \%$ of those who received the COVID-19 vaccine received the influenza vaccine in 2020.) ( $p<0.001)$ (Table 1). In addition, $132(88.6 \%)$ out of 149 individuals who did not accept to receive the COVID-19 vaccine did not receive the vaccine although they worked in a unit at risk for COVID-19.

While the rate of those who received the influenza vaccine in 2019 was $19.1 \%(n=147)$ this rate was $27.5 \%(n=211)$ in 2020 $(p<0.001)$. While $101(68.7 \%)$ out of 147 individuals who received the influenza vaccine in 2019 received the vaccine in 202046 (31.3\%) did not receive the vaccine. On the other hand, while $110(17.7 \%)$ out of 621 individuals who did not receive the influenza vaccine in 2019 received the vaccine in 2020511 (82.3\%) did not receive the vaccine (Table 2). 


\begin{tabular}{|c|c|c|c|}
\hline & \multicolumn{2}{|c|}{ COViD-19 vaccine } & \multirow[b]{2}{*}{$\mathbf{p}$} \\
\hline & $\begin{array}{l}\text { Those who didn't } \\
\text { receive the } \\
\text { vaccine (n;\%) }\end{array}$ & $\begin{array}{l}\text { Those who } \\
\text { received the } \\
\text { vaccine (n;\%) }\end{array}$ & \\
\hline Age (year) & & & $0.207^{*}$ \\
\hline 20-29 years & $40(27.0)$ & $179(28.9)$ & \\
\hline 30-39 years & $67(45.3)$ & $236(38.1)$ & \\
\hline $40-49$ years & $36(24.3)$ & $159(25.7)$ & \\
\hline 50 years and above & $5(3.4)$ & $45(7.3)$ & \\
\hline \multicolumn{4}{|l|}{ Gender } \\
\hline Female & $108(72.5)$ & $408(65.9)$ & $0.125^{*}$ \\
\hline Male & $41(27.5)$ & $211(34.1)$ & \\
\hline Occupation & & & $<0.001 *$ \\
\hline Physician & $63(42.3)$ & $409(66.1)$ & \\
\hline Nurse & $69(46.3)$ & $145(23.4)$ & \\
\hline $\begin{array}{l}\text { Other healthcare } \\
\text { workers }\end{array}$ & $9(11.0)$ & $65(10.5)$ & \\
\hline Chronic Disease & & & $0.452^{*}$ \\
\hline No & $120(80.5)$ & $481(77.7)$ & \\
\hline Yes & $29(19.5)$ & $138(22.3)$ & \\
\hline Suspected COViD contact & & & $0.452^{*}$ \\
\hline No & $17(11.4)$ & $58(9.4)$ & \\
\hline Yes & $132(88.6)$ & $561(90.6)$ & \\
\hline 2019 (influenza)vaccine & & & $<0.001 *$ \\
\hline No & $137(91.9)$ & $484(78.2)$ & \\
\hline Yes & $12(8.1)$ & $135(21.8)$ & \\
\hline 2020 (influenza)vaccine & & & $<0.001 *$ \\
\hline No & $138(92.6)$ & $419(67.7)$ & \\
\hline Yes & $11(7.4)$ & $200(32.3)$ & \\
\hline Total & $149(19.1)$ & $619(80.6)$ & \\
\hline
\end{tabular}

Table 2. Comparison of those who received and who did not receive the influenza vaccine in 2019 and 2020

\begin{tabular}{|c|c|c|c|c|c|c|}
\hline & \multicolumn{2}{|c|}{2019 (influenza) } & \multirow{2}{*}{ Total } & \multirow[b]{2}{*}{ p } \\
\hline & & & No & Yes & & \\
\hline \multirow{6}{*}{$\begin{array}{l}2020 \\
\text { (influenza) }\end{array}$} & & $\mathrm{N}$ & 511 & 46 & & \multirow{6}{*}{$<0.001^{*}$} \\
\hline & No & Row \% & $91.7 \%$ & $8.3 \%$ & $100.0 \%$ & \\
\hline & & Column $\%$ & $82.3 \%$ & $31.3 \%$ & $72.5 \%$ & \\
\hline & & $\mathrm{N}$ & 110 & 101 & 211 & \\
\hline & Yes & Row \% & $52.1 \%$ & $47.9 \%$ & $100.0 \%$ & \\
\hline & & Column \% & $17.7 \%$ & $\mathbf{6 8 . 7} \%$ & $27.5 \%$ & \\
\hline \multirow{3}{*}{ Total } & & $\mathrm{N}$ & 621 & 147 & 768 & \\
\hline & & Row \% & $80.9 \%$ & $19.1 \%$ & $100.0 \%$ & \\
\hline & & Column \% & $100.0 \%$ & $100.0 \%$ & $100.0 \%$ & \\
\hline
\end{tabular}

${ }^{*}$ McNemar's Test

An increase in the rates of having received the influenza vaccine was observed in 2020 compared to 2019 , however, this increase was statistically significant only in the group including the ages of 30-39 and 40-49, male individuals, physicians, and those without a chronic disease $(p<0.05)$. On the contrary, it was not significant in the ages of 20-29 and $\geq 50$, female individuals, nurses and the other healthcare workers, and those with a chronic disease ( $p>0.05$ ) (Table 3).

The most common reason of the participants who received the influenza vaccine in 2020 was the pandemic at a rate of $34 \%$ (shown in Figure 1).
Table 3. Comparison of those who received the influenza vaccine in 2019 and 2020 in terms of age, gender, occupation, presence of a chronic disease, and the institution they worked for (private/public)

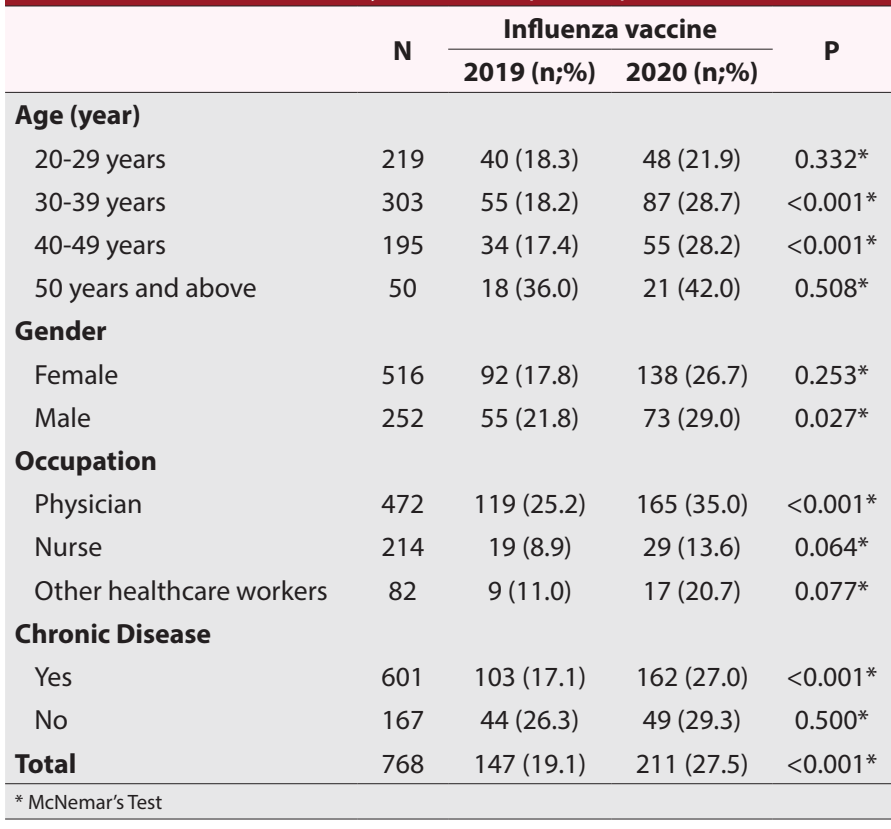

Accepting reasons of those who received the
influenza vaccine this year (n=211)
- 1. I received the vaccine due to COVID-19
pandemic
2. I received the vaccine to protect my family
and patients
3. I am regularly vaccinated every year
4. I received the vaccine because I have a
chronic disease
- 5. I received the vaccine because everyone
received it
6. Other multiple reasons
7. Those who give the 1st and 2nd answer
together.
8. Those who give the 2nd and 3rd answers
together.

Figure 1. Accepting reasons of those who received the influenza vaccine this year

\section{DISCUSSION}

While most of COVID-19 patients have influenza-like symptoms such as fever, coughing and fatigue about $5 \%$ of these patients show rapid progression and are hospitalized in the intensive care unit due to acute respiratory distress syndrome (ARDS), septic shock and multiple organ failure. ${ }^{[7]}$ If the condition that influenza and COVID-19 with similar clinical features are together in circulation especially in winter months is considered it is very important to determine strategies not to experience difficulties in diagnosing or to be able manage the treatments that will be used in the coexistence of these two viruses. According to a study by Simin Ma et al. in China, 44 (about 50\%) out of 95 COVID-19 patients were infected with influenza and most of them were caused by influenza A. It was 
considered that the coexistence of these two viruses causing the same clinical symptoms caused false negative COVID-19 test results and that these results would cause difficulties and delays in diagnosis and increase in the spread of COVID-19. In the same study, it was considered that cytokine storm and organ damage would occur earlier in case of the coexistence with influenza in patients infected with COVID-19. ${ }^{[7]}$ According to some studies, the influenza vaccine may have mechanisms that could affect the pathogenicity of COVID-19. ${ }^{[8,9]}$ Although influenza vaccination has importance every year its importance during the pandemic becomes more obvious due to all these reasons.

In studies, the rate of seasonal influenza vaccination in healthcare workers ranges from $9 \%$ to $92 \%{ }^{[10]}$ In a study we assessed the influenza vaccination of 12,475 healthcare workers in our country, while only $6.7 \%$ of the healthcare workers were regularly vaccinated $18.8 \%$ stated that they were sometimes vaccinated[11] In the study by Kul et al. in our country, 371 individuals were questioned about whether they received the influenza vaccine or not and it was found that $134(36.1 \%)$ of the participants were vaccinated at least once in their lifetime. ${ }^{[12]}$ Of the healthcare workers, 20\% have an influenza-like disease in the influenza season ${ }^{[13]}$ and more than $41 \%$ keep working although they are infected. [14] As a result of this, healthcare-associated influenza epidemics occur. In a study in China, influenza vaccination rates increased during 2009-2020 H1N1 pandemic, but decreased to the rates of 2008-2009 season in 2010-2011 season. However, in a study in Hong Kong, although the WHO declared a second degree alarm vaccination rates did not change. ${ }^{[15]}$ Therefore, how the COVID-19 pandemic will affect the influenza vaccination in healthcare workers is not completely certain. In our study, while the rate of those who received the influenza vaccine in 2019 was $19.1 \%(n=147)$ this rate was $27.5 \%(n=211)$ in 2020 among healthcare workers $(p<0.001)$. In the study assessing the attitudes of nurses toward influenza vaccine during the pandemic in Hong Kong, Wang et al. found that the vaccination rates were similar in 2019 and 2020, but the nurses who did not receive the vaccine in 2019 changed their minds about receiving the vaccine more or being undecided in 2020 and this change was statistically significant $(p<0.001) \cdot{ }^{[16]}$ In our study, the most common reason to receive the vaccine was COVID-19 pandemic (34\%). The main reason of that is probably the increasing awareness on respiratory tract viruses due to the pandemic.

Vaccine hesitancy was declared one of the first ten threats on global health by the World Health Organization in 2019. ${ }^{[17]}$ The reasons of vaccine hesitancy are complicated, but the most common reason of vaccine hesitancy in the healthcare workers is seen to be having insufficient and lacking information about safety of the vaccine. ${ }^{[18]}$ Overcoming the false information and beliefs about the vaccination and convincing people to receive the vaccine should actually be among the main goals. According to the previous studies, it is known that those who accepted the vaccination once kept receiving the vaccines in the following years. ${ }^{[15,19]}$ In our study, it was observed that those who received the influenza vaccine in 2019 accepted vaccination in 2020 as well $(p<0.001)$, but if they did not receive the vaccine in 2019 they did not receive it in 2020, either $(p<0.001)$. According to our study, while influenza vaccination revealed an increase in all occupation groups from 2019 to 2020 the most significant difference was observed in physicians. The rate of COVID-19 vaccination was found to be higher among physicians compared with the other healthcare workers like in the other studies $(p<0.001) .{ }^{[20]}$ The reasons may be that physicians have higher level of education, that diseases that can be prevented by vaccine are known better and that the consequences of influenza are known more due to the pandemic.

While $80.6 \%$ (619) of the participants in our study received the COVID-19 vaccine $19.1 \%$ (149) did not accept to receive the vaccine. It was observed that those who accepted to receive the influenza vaccine in 2019 and 2020 accepted to receive the COVID-19 vaccine and were statistically significantly different from those who did not accept to receive the influenza vaccine $(p<0.001)$. It observed in the study by Wang et al. that those with previous influenza vaccine history were more intended to accept the COVID-19 vaccine (OR: 0.19, 95\%Cl: 0.11-0.32). ${ }^{[16]}$ Similarly, in two separate studies on the healthcare workers and family physicians in Malta, having received the influenza vaccine before was an important determinant in accepting the COVID-19 vaccine. ${ }^{[20,21]}$ Accepting to receive the vaccine is a way of behavior for the individuals ${ }^{[22]}$ and due to this way of behavior, receiving the vaccine is more expected in these individuals in case of diseases with similar transmission routes or similar clinics. Another important point we noticed in our study was that $132(88.6 \%)$ out of 149 individuals who did not accept to receive the COVID-19 vaccine did not receive the vaccine although they worked in a unit at risk for COVID-19. Similarly, although it was expected for those working at high-risk units to accept to receive the vaccine more compared with those working at low-risk units in the study by Wang et al. no significant difference was found between the groups. ${ }^{[16]}$ It is important to investigate the reasons why those working at high-risk units refuse the vaccination and carry out activities encouraging this group with high risk of transmission for vaccination.

Protection of the healthcare workers during the pandemic was defined as the major component of the phase of preparation for the pandemic. ${ }^{[23]}$ As is known all over the world how many people the vaccine reaches as well as the effectiveness of it are among the main goals in vaccination. [24,25] According to our study, the pandemic has positive effects on receiving the influenza vaccine among healthcare workers. However, it is necessary to determine new strategies to convince and encourage those who still have suspects about the influenza and COVID-19 vaccines. 
The strengths of our study are as follows: The questions in the questionnaire were asked to the individuals after influenza and COVID-19 vaccinations started in our country. Not their intents but real data were obtained. The weaknesses of our study can be as follows: The population group was not very large and there was no equal distribution between the occupation groups and age groups.

\section{CONCLUSION}

Many diseases and pandemics worldwide have been overcome thanks to the vaccines. Therefore, it is possible that several pandemics that will occur in the future can end with the discovery of vaccines. The COVID-19 pandemic we experience today have revealed how the presence of a vaccine can affect the whole world. It is observed that even antivaxxers wait for the COVID-19 vaccine and state their requests to return to normal life in all platforms. It is important to develop especially evidence-based vaccination strategies for the healthcare workers. Future studies are needed to remove the hesitations on receiving the influenza vaccine, investigate the changes in accepting to receive the influenza vaccine due to pandemic and investigate the behavioral patterns in the intent of accepting to receive the COVID-19 vaccine.

\section{ETHICAL DECLARATIONS}

Ethics Committee Approval: The study was prospectively performed and approved by the ethics committee of Mustafa Kemal University, Tayfur Ata Sokmen Faculty of Medicine (No: 03 from February 18, 2021).

Informed Consent: All patients signed the free and informed consent form.

Referee Evaluation Process: Externally peer-reviewed.

Conflict of Interest Statement: The authors have no conflicts of interest to declare.

Financial Disclosure: The authors declared that this study has received no financial support.

Author Contributions: All of the authors declare that they have all participated in the design, execution, and analysis of the paper, and that they have approved the final version.

\section{REFERENCES}

1. Grohskopf LA, Alyanak E, Broder KR, et al. Prevention and Control of Seasonal Influenza with Vaccines: Recommendations of the Advisory Committee on Immunization Practices - United States, 2020-21 Influenza Season. MMWR Recomm Rep. 2020;69(8):1-24.

2. Gostin LO, Salmon DA. The Dual Epidemics of COVID-19 and Influenza: Vaccine Acceptance, Coverage, and Mandates. JAMA. 2020;324(4):335-6.

3. Maltezou HC, Theodoridou K, Poland G. Influenza immunization and COVID-19. Vaccine. 2020;38(39):6078-9.

4. Patel A, Jernigan DB. Initial public health response and interim clinical guidance for the 2019 novel coronavirus outbreak-United States, December 31, 2019-February 4, 2020. MMWR 2020;69(5):140.

5. WHO. Director-General's opening remarks at the media briefing on COVID-19;. March 11, 2020( https://www.who.int/dg/speeches/detail/ who-director-general-s-opening-remarks-at-themedia-briefing-oncovid-19---11-march-2020).
6. Hashemi SA, Safamanesh S, Ghafouri M, et al. Co-infection with COVID-19 and influenza $A$ virus in two died patients with acute respiratory syndrome, Bojnurd, Iran. J Med Virol. 2020;92(11):2319-21.

7. Ma S, Lai X, Chen Z, Tu S, Qin K. Clinical characteristics of critically ill patients co-infected with SARS-CoV-2 and the influenza virus in Wuhan, China. Int J Infect Dis. 2020;96:683-7.

8. Earnest JT, Hantak MP, Park JE, Gallagher T. Coronavirus and influenza virus proteolytic priming takes place in tetraspanin-enriched membrane microdomains. J Virol. 2015;89(11):6093-104.

9. Eldanasory OA, Rabaan AA, Al-Tawfiq JA. Can influenza vaccine modify COVID-19 clinical course?. Travel Med Infect Dis. 2020;37:101872.

10. Prematunge C, Corace K, McCarthy A, Nair RC, Pugsley R, Garber G. Factors influencing pandemic influenza vaccination of healthcare workers--a systematic review. Vaccine. 2012;30(32):4733-43.

11. Korkmaz N, Nazik S, Gümüştakım RŞ, et al. Influenza vaccination rates, knowledge, attitudes and behaviours of healthcare workers in Turkey: A multicentre study. Int J Clin Pract. 2021;75(1):e13659.

12. Kul G, Korkmaz N. Sağlık Çalışanlarının İnfluenza Aşısına Yaklaşımı. J Contemp Med. 2020;10(3):421-4.

13. Kuster SP, Shah PS, Coleman BL, et al. Incidence of influenza in healthy adults and healthcare workers: a systematic review and meta-analysis. PLoS One. 2011;6(10):e26239.

14. Chiu S, Black CL, Yue $X$, et al. Working with influenza-like illness: Presenteeism among US health care personnel during the 2014-2015 influenza season. Am J Infect Control. 2017;45(11):1254-8.

15. Chor JSY, Ngai KL, Goggins WB, et al. Willingness of Hong Kong healthcare workers to accept pre-pandemic influenza vaccination at different WHO alert levels: two questionnaire surveys BMJ 2009; 339:b3391

16. Wang K, Wong ELY, Ho KF, et al. Intention of nurses to accept coronavirus disease 2019 vaccination and change of intention to accept seasonal influenza vaccination during the coronavirus disease 2019 pandemic: A cross-sectional survey. Vaccine. 2020;38(45):7049-56.

17. Geoghegan S, O'Callaghan KP, Offit PA. Vaccine Safety: Myths and Misinformation. Front Microbiol. 2020;11:372.

18. Millner VS, Eichold BH 2nd, Franks RD, Johnson GD. Influenza vaccination acceptance and refusal rates among health care personnel. South Med J. 2010;103(10):993-8.

19. Liao Q, Cowling BJ, Lam WW, Fielding R. Factors affecting intention to receive and self-reported receipt of 2009 pandemic $(\mathrm{H} 1 \mathrm{~N} 1)$ vaccine in Hong Kong: a longitudinal study. PLoS One. 2011;6(3):e17713.

20. Grech V, Gauci C, Agius S. Withdrawn: Vaccine hesitancy among Maltese Healthcare workers toward influenza and novel COVID-19 vaccination. Early Hum Dev. 2020;105213.

21. Grech V, Bonnici J, Zammit D. WITHDRAWN: Vaccine hesitancy in Maltese family physicians and their trainees vis-à-vis influenza and novel COVID-19 vaccination. Early Hum Dev. 2020;105259.

22. Lin CJ, Nowalk MP, Toback SL, et al. Importance of vaccination habit and vaccine choice on influenza vaccination among healthy working adults. Vaccine. 2010;28(48):7706-12.

23. Zarocostas J. Healthcare workers should get top priority for vaccination against A/H1N1 flu, WHO says. BMJ. 2009;339:b2877.

24. Nuño M, Chowell G, Gumel AB. Assessing the role of basic control measures, antivirals and vaccine in curtailing pandemic influenza: scenarios for the US, UK and the Netherlands. J R Soc Interface. 2007;4(14):505-21.

25. Hughes MM, Reed C, Flannery B, et al. Projected Population Benefit of Increased Effectiveness and Coverage of Influenza Vaccination on Influenza Burden in the United States. Clin Infect Dis. 2020;70(12):2496502. 